\title{
Evaluation of Immunomodulatory Properties After Oral Administration of Biofield Energy Treated Test Formulation in Sprague Dawley Rats: Influence of the Trivedi Effect ${ }^{\circledR}$
}

\author{
Mahendra Kumar Trivedi ${ }^{1}$, Alice Branton ${ }^{1}$, Dahryn Trivedi ${ }^{1}$, Gopal Nayak ${ }^{1}$, \\ Barry Dean Wellborn ${ }^{1}$, Deborah Lea Smith ${ }^{1}$, Dezi Ann Koster ${ }^{1}$, Elizabeth Patric ${ }^{1}$, Jagdish Singh ${ }^{1}$, \\ Kathleen Starr Vagt ${ }^{1}$, Krista Joanne Callas ${ }^{1}$, Sambhu Charan Mondal ${ }^{2}$, Snehasis Jana ${ }^{2, *}$ \\ ${ }^{1}$ Trivedi Global, Inc., Henderson, Nevada, USA \\ ${ }^{2}$ Trivedi Science Research Laboratory Pvt. Ltd., Bhopal, Madhya Pradesh, India
}

Email address:

publication@trivedieffect.com (S. Jana)

${ }^{*}$ Corresponding author

\section{To cite this article:}

Mahendra Kumar Trivedi, Alice Branton, Dahryn Trivedi, Gopal Nayak, Barry Dean Wellborn, Deborah Lea Smith, Dezi Ann Koster, Elizabeth Patric, Jagdish Singh, Kathleen Starr Vagt, Krista Joanne Callas, Sambhu Charan Mondal, Snehasis Jana. Evaluation of Immunomodulatory Properties After Oral Administration of Biofield Energy Treated Test Formulation in Sprague Dawley Rats: Influence of the Trivedi Effect ${ }^{\circledR}$. American Journal of Biomedical and Life Sciences. Vol. 5, No. 6, 2017, pp. 154-162. doi: 10.11648/j.ajbls.20170506.17

Received: October 30, 2017; Accepted: November 11, 2017; Published: December 11, 2017

\begin{abstract}
A new proprietary herbomineral formulation was formulated, consisting of an essential ingredients viz. an herbal root extract ashwagandha and minerals (zinc, magnesium, and selenium). The aim of this study was to evaluate the immunomodulatory potential of Energy of Consciousness Healing (The Trivedi Effect ${ }^{\mathbb{B}}$ ) Treatment on the herbomineral formulation in male Sprague Dawley rats. The test formulation was divided into two parts. One part was denoted as the control without any Biofield Energy Treatment, while the other part was defined as the Biofield Energy Treated sample, which received the Biofield Energy Healing Treatment remotely from seven renowned Biofield Energy Healers. Additionally, one group of animals was also received Biofield Energy Treatment per se (day -15) by Biofield Energy Healers under similar conditions. The immunological parameters viz. humoral immune analysis, paw volume, hematological study, biochemistry, body weight, feed and water intake, and histopathology analysis were performed in this experiment. The humoral immune response data showed the secondary antibody titre was significantly increased by $112.50 \%$ and $87.50 \%$ in the Biofield Energy Treated test formulation group (G4) and untreated test formulation group (G5) compared to the disease control group (G2). The results of delayed type hypersensitivity showed significant increased the paw volume by $111.76 \%, 51.45 \%, 100 \%$, and $64.80 \%$ in the G4, G5, Biofield Energy Treatment group per se at day -15 (G6) and Biofield Energy Treated test formulation at day -15 (G7) groups, respectively compared to the G2 group. The platelet count was significantly increased by $37.72 \%, 8.69 \%$, $16.30 \%$ and $33.11 \%$ in the G4, G5, G6, and G7 groups, respectively compared to the G2 group. The level of blood urea nitrogen was significantly decreased by $14.01 \%$ in the G4 group compared to the disease control. Moreover, the concentration of uric acid was significantly reduced by $28.97 \%$ in the G7 group compared to the G2 group. Animal weight parameters suggested that there were no treatment-related changes in any group. Organ to body weight ratio, feed and water intake data described that the Biofield Energy Treated test formulation was found to be safe without any side-effect during the course of the experiment. Overall, results suggested that the Biofield Energy Treated herbomineral formulation and Biofield Energy Treatment per se can be used for autoimmune and inflammatory diseases, stress management and prevention, and anti-aging by improving overall health.
\end{abstract}

Keywords: Biofield Energy Healers, The Trivedi Effect ${ }^{\circledR}$, Immunomodulation, Herbomineral Formulation, Humoral Immune Response, Delay Type Hypersensitivity, Stress Management, Anti-aging 


\section{Introduction}

The immune system of vertebrate is classified as innate system and the adaptive system. For proper functioning of the immune-reaction it is necessary to interact between the two systems. The innate type of immune system that appears to be an evolutionarily with lacks of specificity and efficiency, but it responds rapidly [1]. Immunomodulation is a process, in which an organism can homeostat the immune response by either stimulating or suppressing of the immune system in the cells and organs [2,3]. Upon activation of the adaptive immune system by the influence of the innate immune system, the humoral immune response can triggers the specific $B$ cells to develop into plasma cells. Consequently, these plasma cells can secrete large amounts of antibodies [4]. The Complementary and Alternative Medicine (CAM) has increased globally for the treatment and prevention of many chronic diseases in human population [5]. A numerous literatures reported that the herbal remedies are amongst the most prevalent therapies due to lack of the adverse effects and low cost [6]. Recently, a new proprietary herbomineral formulation was formulated, which was a combination of an ashwagandha root extract along with trace elements such as zinc, magnesium, and selenium for immunomodulatory activity. The immunomodulatory activity of Withania somnifera (ashwagandha) root extract in experimental immune inflammation was reported by Agarwal et al. [7]. Minerals like zinc plays an important role in most of the vital biochemical reaction in living organism due to its enzyme catalyzing activity. Herbomineral formulations are reported to improve the general health by increasing the body's immunity. However, the combination of herbal and minerals might be a new and improved product for regulation of the immune system [8,9].

Scientific research has been reported that combination of the minerals and herbal medicines have been found to exhibit a high level of phagocytic index and improved antibody titre [10]. This herbomineral formulation can be used for better therapeutic effect in immune compromised patients that are affected by the cardiovascular diseases, age, stress related diseases, cancer, and autoimmune disorders. Along with the herbomineral formulations, the Biofield Energy Healers in this study have used Energy Medicine (Biofield Energy Healing Treatment) as a complementary and alternative approach to study the impact of Biofield Energy Treatment on the herbomineral formulation for its immunomodulatory potential in male Sprague Dawley rats. In recent years, several scientific reports and clinical trials have revealed the useful effects of the Biofield Energy Treatment, which has showed an enhanced immune function in case of cervical cancer patients with therapeutic touch [11], massage therapy [12], etc. Amidst many CAM therapies, there have been an extensive number of scientific reports that showed Biofield Therapy (or Healing Modalities) as preferred model of treatment with several benefits to enhance physical, mental and emotional human wellness.
The National Center of Complementary and Integrative Health (NCCIH) has been recognized and accepted Biofield Energy Healing as a CAM health care approach in addition to other therapies, medicines and practices such as natural products, deep breathing, yoga, Tai Chi, Qi Gong, chiropractic/osteopathic manipulation, meditation, massage, special diets, homeopathy, progressive relaxation, guided imagery, acupressure, acupuncture, relaxation techniques, hypnotherapy, healing touch, movement therapy, pilates, rolfing structural integration, mindfulness, Ayurvedic medicine, traditional Chinese herbs and medicines, naturopathy, essential oils, aromatherapy, Reiki, and cranial sacral therapy. Human Biofield Energy has subtle energy that has the capacity to work in an effective manner [13]. CAM therapies have been practiced worldwide with reported clinical benefits in different health disease profiles [14]. Biofield Energy Healing Treatment has gained rapid rapport as a holistic alternative and complementary medicine therapy that has significant impact on living organisms and nonliving materials without any adverse effects and in a manner that is more cost-effective than more conventional methods. Biofield Energy Treatment (The Trivedi Effect ${ }^{\circledR}$ ) results has been published in numerous peer-reviewed science journals with significant outcomes in many scientific fields such as cancer research [15], microbiology [16-18], biotechnology [19], genetics [20, 21], pharmaceutics [22, 23], nutraceuticals [24], organic compounds [25, 26], agricultural science [27$29]$, and altered the structure of the atom in many metals, ceramics, polymers and chemicals in materials science [3032]. In this study, the authors sought to explore the impact of the Biofield Energy Treatment (The Trivedi Effect ${ }^{\circledR}$ ) on the given herbomineral formulation and Biofield Energy Treatment per se to the animals, which might improve the immunomodulatory function with respect to the antibody titre, delayed type hypersensitivity reaction, body weight change, feed consumption, hematological parameters, and serum biochemistry using standard assays.

\section{Materials and Methods}

\subsection{Chemicals and Reagents}

Cyclophosphamide and carboxymethyl cellulose sodium were purchased from Sigma Chemical Co. (St. Louis, MO). Withania somnifera (Ashwagandha) root extract powder ( $\geq 5 \%$ of total withanolides) was procured from Sanat Products Ltd., India. Zinc chloride and magnesium (II) gluconate hydrate were procured from TCI, Japan. Sodium selenate was procured from Alfa Aesar, USA. Levamisole hydrochloride was procured from Sigma, USA. All other chemicals used were of analytical grade available in India.

\subsection{Laboratory Animals}

A total number of 56 healthy male Sprague Dawley rats, weighing between 220-250 grams, were used for the study ( $n=8$, in each group). The animals were purchased from $M / s$. 
Vivo Bio Tech Ltd., Hyderabad, India. Standard rodent diet was procured from M/s. Golden feeds, Mehrauli, New Delhi, India and provided ad libitum to all the groups of animals during the experiment under controlled conditions with a temperature of $22 \pm 3{ }^{\circ} \mathrm{C}$, humidity of $30 \%$ to $70 \%$ and a 12 hour light/12-hour dark cycle. The animals were acclimatized for 5 days prior to the experiment, and all were accessed once daily for clinical signs, behaviors, morbidity and mortality. All the procedures were in strict accordance with the Guide for the Care and Use of Laboratory Animals published by the US National Institutes of Health. The approval of the Institutional Animal Ethics Committee that was obtained prior to carrying out the animal experiment.

\subsection{Biofield Energy Treatment Strategies}

The test formulation was divided into two parts. One part of the test formulation was treated with the Biofield Energy by renowned Biofield Energy Healers (also known as The Trivedi Effect ${ }^{\circledR}$ ) and coded as the Biofield Energy Treated formulation, while the second part of the test formulation did not receive any sort of treatment and was defined as the untreated test formulation. This Biofield Energy Treatment was provided through a group of seven Biofield Energy Healers who participated in this study and performed the Biofield Energy Treatment remotely were located in the U.S.A., while the test herbomineral formulation was located in the research laboratory of Dabur Research Foundation, New Delhi, India. Additionally, one group of animals was also received the Biofield Energy Treatment per se by the Biofield Energy Healers under similar conditions. This Biofield Energy Treatment was administered for 5 minutes through the Healer's unique Energy Transmission process remotely to the test formulation under laboratory conditions. None of the Biofield Energy Healers in this study visited the laboratory in person, nor had any contact with the herbomineral samples. Further, the control group was treated with a "sham" healer for comparative purpose. The sham healer did not have any knowledge about the Biofield Energy Treatment. After that, the Biofield Energy Treated and untreated samples were kept in similar sealed conditions and used for identification of immunological parameters.

\subsection{Antigen (Sheep RBC)}

The fresh sheep blood was collected aseptically from the jugular vein of a healthy sheep and transferred immediately to the heparinized tube. The collected erythrocytes were separated from plasma by centrifugation $\left(400 \mathrm{~g}, 10^{\circ} \mathrm{C}, 10\right.$ minutes), washed twice with the normal saline and then further diluted in saline, which were analyzed using Hematology analyzer (Abbott Model-CD-3700). Based on the number of erythrocytes, the samples were further diluted (using saline) before injecting to the rats [33].

\subsection{Experimental Procedure}

Seven days after acclimatization, the animals were grouped based on their body weight. A total of seven groups
(G) were included i.e. $G 1$ to $G 7$ with eight animals $(n=8)$ in each group. The animals of G2 to G7 were received cyclophosphamide at a dose of $10 \mathrm{mg} / \mathrm{kg}$ in normal saline through intraperitoneal (i.p.) route 1 hour before administration of test formulation from day 1 to 13 in all the groups except G1. However, G1, G2, and G6 groups were administered with the test item's formulation vehicle $(0.5 \%$ carboxy methyl cellulose-sodium salt) via oral gavage. G3 animals were received reference item, levamisole at the rate of $75 \mathrm{mg} / \mathrm{kg}$ body weight. G4 animals were received the Biofield Energy Treated test formulation at $1105.005 \mathrm{mg} / \mathrm{kg}$ b.wt, per-oral (p.o.), and G5 animals were received the untreated test formulation at the same dose by oral route. Further, G6 animals were received Biofield Energy Treatment per se at day -15 , while G7 animals were received the Biofield Energy Treated test formulation at day -15 . The treatment was continued to all the tested groups (G1 to G7) for 26 days with $5 \mathrm{~mL} / \mathrm{kg}$ body weight dose volume. All animals (G1-G7) were challenged with sheep red blood cells (sRBC) $\left(0.5 \times 10^{9}\right.$ cells $/ 100$ gm; i.p. $)$ on day 7 and 13 , as the antigenic material to sensitize them for immunological studies. On day $13^{\text {th }}$ and $20^{\text {th }}$ the animals were bled and the samples were subjected to hemagglutination test to evaluate humoral immune response. Again, on day $20^{\text {th }}$, animals were challenged with sRBC $\left(0.5 \times 10^{9}\right.$ cells $\left./ 50 \mu \mathrm{L} / \mathrm{rat}\right)$ in subplanter region and paw volume was measured at both 24 hours and 48 hours to evaluate cellular immune response. The body weight and feed consumption were measured daily. The animals were kept under fasting overnight on day 24 after. In the next day, blood was collected from retro-orbital plexus from each animal under isoflurane anaesthesia. Whole blood was analysed for haematological parameters and serum was analysed for serum biochemistry. At the end of the study, animals were euthanized by $\mathrm{CO}_{2}$ asphyxiation as per inhouse approved standard protocol. Different organs of all animals were excised, weighed and preserved for histopathological analysis.

\subsection{Determination of Humoral Immune Response}

The blood was withdrawn from the retro-orbital plexus of all antigenically challenged rats on day $13^{\text {th }}$ and $20^{\text {th }}$. Approximately $25 \mu \mathrm{L}$ of serum was serially diluted with the $25 \mu \mathrm{L}$ of phosphate-buffered saline. The $\operatorname{sRBC}\left(0.025 \times 10^{9}\right.$ cells) was added to each of these dilutions and incubated at $37^{\circ} \mathrm{C}$ for 1 hour. The rank of minimum dilution that exhibited hemagglutination was considered as an antibody titre. The level of antibody titre on day 13 of the experiment was considered as the "primary humoral immune response" and the day 20 was considered as the "secondary humoral immune response" [34].

\subsection{Determination of Paw Volume (Delayed Type Hypersensitivity)}

The cellular immune response was assayed by the footpad reaction method. The edema was induced in the right paw of rats by injecting $\mathrm{sRBC}\left(0.025 \times 10^{9}\right.$ cells $)$ in the sub-plantar 
region. The paw volume was assessed on digital plethysmometer (Pan Lab, Spain). The mean percentage increase in paw volume was considered as delayed type of hypersensitivity and as an index of cell-mediated immunity. The volume of the left hind paw, injected similarly with phosphate-buffered saline, served as control.

\subsection{Determination of Hematological and Biochemical Parameters}

An aliquot of blood were directly subjected for the estimation of various hematological parameters using standard instrument. Remaining volume of blood was used for the isolation of serum and stored for biochemical analysis. The various hematological parameters were measured such as hemoglobin (Hb), red blood count (RBC), packed cell volume (PCV), mean corpuscular volume (MCV), mean corpuscular hemoglobin (MCH), mean corpuscular hemoglobin concentration (MCHC) and platelets. Further, the levels of magnesium, blood urea nitrogen (BUN), creatinine, uric acid, calcium, phosphorus, potassium, sodium, and chloride ion concentration were analyzed in serum sample using Hematology analyzer (Abbott Model-CD-3700) [35].

\subsection{Determination of Body Weight, Feed Intake and Water Intake}

The body weight, feed intake, and water intake were measured once daily throughout the experiment. Briefly, in feed intake, the weight of daily feed supply and the left-over by the following day was recorded and the difference was taken as the daily feed intake [36].

\subsection{Assessment of Clinical Signs and Symptoms}

The clinical signs were observed once daily in all the animals in accordance with the in-house protocol [37]. Animals found in a moribund condition or enduring signs of severe distress was humanely euthanized.

\subsection{Measurement of Relative Organ Weight and Histopathology}

At the end of the experiment, rats were dissected. Various organs viz. the whole liver, lungs, kidneys, brain, hearts, eyes, spleens, duodenum, jejunum, ileum, caecum, colon, rectum, testis, prostate, epididymis, vas-deference, and pancreas were isolated, weighed, and kept for histopathological examination. The organ to body weight ratio was determined by comparing the weight of each organ with the final body weight of each rat. Defined samples were placed in $10 \%$ neutral buffered formalin for histopathological examination.

\subsection{Statistical Analysis}

Data were expressed as mean \pm standard error of mean (SEM) and subjected to Student's $t$-test using Sigma Plot (11.0) statistical software. Statistical significance was considered at $p \leq 0.05$.

\section{Results and Discussion}

\subsection{Effect of Test Formulation on Humoral Immune Response}

The effect of the test formulation on primary and secondary antibody titre values in rats is summarized in the Table 1 . The primary response of mean hemagglutination (HA) antibody titre was significantly $(p \leq 0.001)$ decreased by $96.43 \%$ in the disease control group (G2) compared to the normal control (G1). The secondary response of mean HA titre was also significantly $(p \leq 0.001)$ decreased by $80 \%$ in the G2 group compared to the G1 group. It was indicated that cyclophosphamide remarkably suppressed the immunoresponse as evidenced by lowered the levels of both primary and secondary antibody titre. The secondary HA titre was significantly elevated by $112.50 \%$ in the Biofield Energy Treated test formulation (G4) compared to the G2 group. Besides, the primary and secondary HA titre levels were increased by $163.00 \%$ and $87.50 \%$, respectively in the untreated test formulation (G5) compared to the G2 group. It is assumed that an increased level of secondary antibody titre in the Biofield Energy Treated test formulation (G4) might be due to Biofield Energy Healing Treatment to the test formulation. These results provided a valuable information about the influence of Biofield Energy Healing on the secondary humoral immune responses in male rats.

Table 1. The effect of the test formulation on humoral immune response in male Sprague Dawley rats.

\begin{tabular}{lll}
\hline Group & Primary HA Titre & Secondary HA Titre \\
\hline G1 & $28.00 \pm 2.62$ & $10.00 \pm 1.31$ \\
G2 & $1.00 \pm 0.53^{* * *}$ & $2.00 \pm 0.76^{* * *}$ \\
G3 & $1.25 \pm 0.98$ & $1.25 \pm 0.49$ \\
G4 & $1.00 \pm 0.46$ & $4.25 \pm 1.22$ \\
G5 & $2.63 \pm 1.94$ & $3.75 \pm 1.82$ \\
G6 & $0.75 \pm 0.16$ & $0.75 \pm 0.49$ \\
G7 & $1.00 \pm 0.27$ & $1.29 \pm 0.49$ \\
\hline
\end{tabular}

HA: Hemagglutination; G1: Normal Control; G2: Disease Control: G3: Levamisole; G4: Biofield Energy Treated test formulation; G5: Untreated test formulation; G6: Biofield Energy Healing Treatment group per se (day 15); G7: Biofield Energy Treated test formulation (day -15). All the values are expressed as the mean \pm SEM. ${ }^{* * *} p \leq 0.001$ compared with the normal control $(\mathrm{n}=8)$.

\subsection{Effect of the Test Formulation on Paw Volume (Delayed Type Hypersensitivity)}

The effect of the test formulation on delayed type hypersensitivity (DTH) response, is shown in the Figure 1 (A and B). The animals administered with the Biofield Energy Treated test formulation (G4), untreated test formulation (G5), Biofield Energy Healing Treatment per se at day -15 (G6) and Biofield Energy Treated test formulation at day -15 (G7) showed $111.76 \%, 51.45 \%, 100 \%$, and $64.80 \%$ increase in DTH response, respectively compared to the disease control (G2) at 24 hours while; non-significant changes in paw volume were observed across the groups at 48 hours. Literature reported that ashwagandha had increased the paw volume in animal [38], while mineral complex such as zinc 
was also reported to increase the delayed type hypersensitivity reaction [39]. Zinc and magnesium present in the test formulation were also reported to be safe, important, and have good therapeutic action [40]. So, it can be concluded with these data that the constituents present in the test formulation were responsible for delayed type hyper sensitivity reaction, but Biofield Energy Treatment (The Trivedi Effect $^{\mathbb{B}}$ ) further enhanced the cell mediated immune response compared with the untreated test formulation.
A. 24 Hours

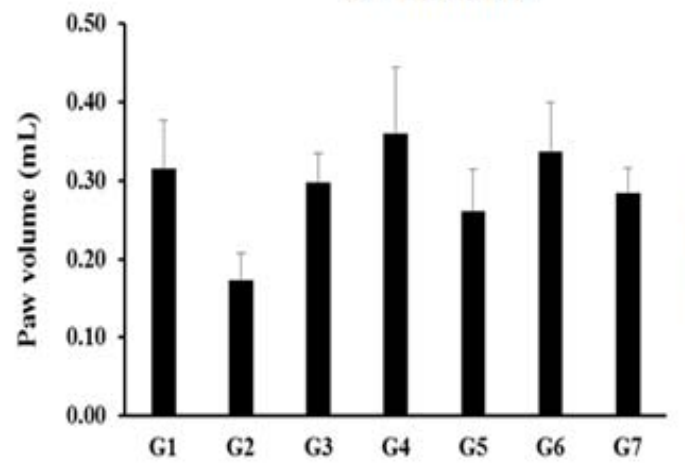

B. 48 Hours

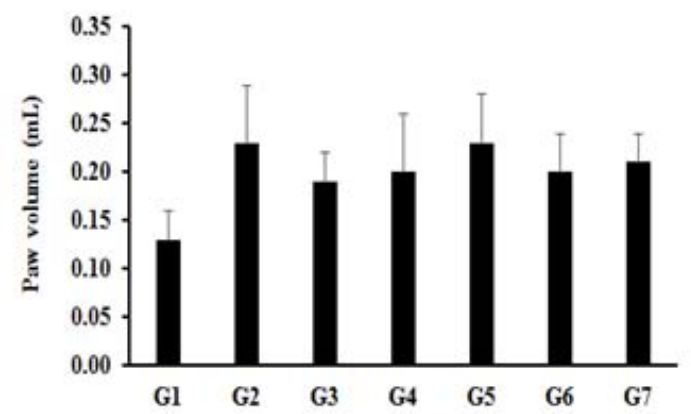

Figure 1. Effect of the test formulation on rat paw volume (delayed-type hypersensitivity) A. 24 hours and B. 48 hours. G1: Normal Control; G2: Disease Control: G3: Levamisole; G4: Biofield Energy Treated test formulation; G5: Untreated test formulation; G6: Biofield Energy Treatment per se (day -15); G7: Biofield Energy Treated test formulation (day-15). All values are expressed as the mean $\pm \operatorname{SEM}(n=8)$.

\subsection{Effect of the Test Formulation on Hematology Parameters}

The effect of the test formulation on hematological parameters is shown in the Table 2. Results showed the platelet count was significantly increased by $37.72 \%$, $18.06 \%, 16.30 \%$, and $33.11 \%$ in the Biofield Energy Treated test formulation (G4) and untreated test formulation (G5), Biofield Energy Treatment group per se at day -15 (G6) and Biofield Energy Treated test formulation at day -15 (G7), respectively compared with the disease control $(\mathrm{G} 2)$ group. It was indicated that the Biofield Energy Treated test formulation showed more increment of platelets counts compared to the untreated test formulation. From literature, it was reported that ashwagandha prevented myelosuppression with increased platelet count and body weight [41, 7] in rats. Our experimental results also showed increase platelet count which was well corroborated with the literature observation. The mean corpuscular hemoglobin concentration (MCHC) was slightly increased in all the treatment groups (G3 - G7) except G3, where the value was slightly reduced as compared to the disease control $(\mathrm{G} 2)$. Rest of the parameters such as $\mathrm{RBC}, \mathrm{Hb}, \mathrm{PCV}, \mathrm{MCV}$ and $\mathrm{MCH}$ of which groups were altered, however did not show any significant results compared to the disease control $(\mathrm{G} 2)$.

Table 2. Evaluation of hematology parameters of the test formulation in male Sprague Dawley rats.

\begin{tabular}{|c|c|c|c|c|c|c|c|c|}
\hline Group & $\begin{array}{l}\text { RBC } \\
\left(10^{6} / \mu \mathrm{L}\right)\end{array}$ & $\begin{array}{l}\text { Hb } \\
(\mathrm{gm} / \mathrm{dL})\end{array}$ & $\begin{array}{l}\text { PCV } \\
(\%)\end{array}$ & $\begin{array}{l}\text { MCV } \\
\text { (fl) }\end{array}$ & $\begin{array}{l}\text { MCH } \\
\text { (pg) }\end{array}$ & $\begin{array}{l}\text { MCHC } \\
(\%)\end{array}$ & $\begin{array}{l}\text { Platelet Count } \\
\text { (thousand } / \mathrm{mm}^{3} \text { ) }\end{array}$ & RDW-CV \\
\hline G1 & $9.82 \pm 0.16$ & $15.84 \pm 0.11$ & $56.29 \pm 72$ & $57.55 \pm 1.51$ & $16.09 \pm 0.26$ & $28.11 \pm 0.43$ & $655.75 \pm 70.30$ & $0.13 \pm 0.00$ \\
\hline G2 & $9.27 \pm 0.17$ & $15.66 \pm 0.29$ & $54.20 \pm 1.12$ & $58.53 \pm 0.44$ & $16.85 \pm 0.13$ & $28.86 \pm 0.30$ & $606.38 \pm 52.87$ & $0.16 \pm 0.00$ \\
\hline G3 & $8.65 \pm 0.22$ & $14.41 \pm 0.33$ & $50.63 \pm 1.67$ & $58.54 \pm 0.64$ & $16.63 \pm 0.21$ & $28.50 \pm 0.39$ & $780.38 \pm 80.83$ & $0.16 \pm 0.00$ \\
\hline G4 & $9.30 \pm 0.24$ & $15.63 \pm 0.31$ & $51.54 \pm 1.22$ & $55.55 \pm 0.82$ & $16.80 \pm 0.34$ & $30.31 \pm 0.40^{*}$ & $835.13 \pm 116.17$ & $0.14 \pm 0.00$ \\
\hline G5 & $8.92 \pm 0.23$ & $15.43 \pm 0.41$ & $49.74 \pm 1.30$ & $55.83 \pm 0.52$ & $17.25 \pm 0.11$ & $30.98 \pm 0.18^{* * *}$ & $715.88 \pm 80.21$ & $1.92 \pm 1.78$ \\
\hline G6 & $8.56 \pm 0.47$ & $14.39 \pm 0.90$ & $47.49 \pm 2.84$ & $55.49 \pm 1.08$ & $16.73 \pm 0.33$ & $30.19 \pm 0.39^{*}$ & $705.25 \pm 79.46$ & $0.14 \pm 0.00$ \\
\hline
\end{tabular}

G1: Normal Control; G2: Disease Control: G3: Levamisole; G4: Biofield Energy Treated test formulation; G5: Untreated test formulation; G6: Biofield Energy Treatment per se (day -15); G7: Biofield Energy Treated test formulation (day -15). RBC: Red blood cells, Hb: Hemoglobin; PCV: Packed cell volume; MCV: Mean corpuscular volume; MCH: Mean corpuscular hemoglobin; MCHC: Mean corpuscular hemoglobin concentration; RDW-CV: Red cell distribution width - coefficient of variation. All the values are expressed as the mean \pm SEM. * $p \leq 0.05$ and $* * * p \leq 0.001$ compared to the disease control.

\subsection{Effect of the Test Formulation on Biochemical Parameters}

The effect of the test formulation on different biochemical parameters is shown in the Table 3. The level of blood urea nitrogen (BUN) was significantly decreased by $14.01 \%$, $12.44 \%, 10.61 \%$, and $14.58 \%$ in the Biofield Energy Treated test formulation group (G4), untreated test formulation (G5), Biofield Energy Treatment group per se at day -15 (G6), and
Biofield Energy Treated test formulation at day -15 (G7), respectively compared to the disease control $(\mathrm{G} 2)$. The concentration of uric acid (UA) was significantly reduced by $9.66 \%, 24.14 \%$, and $28.97 \%$ in the G4, G5, and G7, respectively compared to the G2 group. Here, the Biofield Energy Treated test formulation at day -15 (G7) showed highest beneficial effect by significantly reducing the concentration of UA than the untreated test formulation (G5). 
Besides, the levels of magnesium, creatinine, calcium, phosphorous, and ions like sodium, potassium, and chloride were altered in all the tested groups to some extent but did not show any significant difference with respect to the disease control (G2). Altogether, on the assessment of serum chemistry profile, there was a significant reduction in the levels of serum BUN and UA in the Biofield Energy Treated test formulation group (G4) compared to the disease control group.

Table 3. Effect of the test formulation on biochemical parameters in male Sprague Dawley rats.

\begin{tabular}{|c|c|c|c|c|c|c|c|c|c|}
\hline Group & $\begin{array}{l}\text { Magnesium } \\
(\mathrm{mg} / \mathrm{dL})\end{array}$ & $\begin{array}{l}\text { Blood Urea } \\
(\mathrm{mg} / \mathrm{dL})\end{array}$ & $\begin{array}{l}\text { Creatinine } \\
(\mathrm{mg} / \mathrm{dL})\end{array}$ & $\begin{array}{l}\text { Uric Acid } \\
\text { (mg/dL) }\end{array}$ & $\begin{array}{l}\text { Calcium } \\
(\mathrm{mg} / \mathrm{dL})\end{array}$ & $\begin{array}{l}\text { Phosphorus } \\
\text { (mg/dL) }\end{array}$ & $\mathrm{Na}^{+}(\mathrm{Meq} / \mathrm{L})$ & $\mathbf{K}^{+}(\mathbf{m E q} / \mathbf{L})$ & $\mathrm{Cl}^{-}(\mathbf{m E q} / \mathbf{L})$ \\
\hline G1 & $9.38 \pm 0.03$ & $54.51 \pm 3.00$ & $0.25 \pm 0.02$ & $2.13 \pm 0.24$ & $11.81 \pm 0.11$ & $9.60 \pm 0.28$ & $146.15 \pm 0.91$ & $4.81 \pm 0.07$ & $105.25 \pm 1.73$ \\
\hline G2 & $9.33 \pm 0.04$ & $56.26 \pm 1.90$ & $0.27 \pm 0.02$ & $1.45 \pm 0.11$ & $11.68 \pm 0.06$ & $9.71 \pm 0.15$ & $146.70 \pm 1.03$ & $4.58 \pm 0.12$ & $105.88 \pm 1.22$ \\
\hline G3 & $6.41 \pm 0.90$ & $62.63 \pm 2.12$ & $0.35 \pm 0.02$ & $1.41 \pm 0.12$ & $11.99 \pm 0.17$ & $10.78 \pm 0.23$ & $146.13 \pm 1.14$ & $4.85 \pm 0.07$ & $105.88 \pm 1.49$ \\
\hline G4 & $4.38 \pm 0.0 .07$ & $48.38 \pm 2.35$ & $0.29 \pm 0.04$ & $1.31 \pm 0.15$ & $11.32 \pm 0.14$ & $9.65 \pm 0.25$ & $147.76 \pm 0.89$ & $4.89 \pm 0.07$ & $102.75 \pm 1.24$ \\
\hline G5 & $4.40 \pm 0.0 .03$ & $49.26 \pm 3.33$ & $0.29 \pm 0.01$ & $1.10 \pm 0.11$ & $11.11 \pm 0.07$ & $10.09 \pm 0.22$ & $146.56 \pm 0.92$ & $4.74 \pm 0.09$ & $104.38 \pm 1.16$ \\
\hline G6 & $4.38 \pm 0.07$ & $50.56 \pm 3.21$ & $0.36 \pm 0.07$ & $1.61 \pm 0.16$ & $11.54 \pm 0.20$ & $10.11 \pm 0.38$ & $146.64 \pm 0.70$ & $4.83 \pm 0.11$ & $105.38 \pm 1.75$ \\
\hline
\end{tabular}

G1: Normal Control; G2: Disease Control: G3: Levamisole; G4: Biofield Energy Treated test formulation; G5: Untreated test formulation; G6: Biofield Energy Treatment per se (day -15); G7: Biofield Energy Treated test formulation (day -15). All values are expressed as the mean \pm SEM ( $\mathrm{n}=8$ ).

\subsection{Effect of the Test Formulation on Body Weight, Feed and Water Intake, and Organ to Body Weight Ratio}

The effect of the Biofield Energy Treated test formulation administration on animal weight parameters in male rats was analyzed and presented in Table 4. It was found that there was a gradual increment of body weight of the animals in all groups with respect to the initial and final body weights. There was no significant alteration observed in the feed and water intake in all the groups. These findings suggested that there was no significant changes observed in terms of body weight, feed intake, and water intake. Based on this, it is assumed that the oral administration of Biofield Energy Treated test formulation and Biofield Energy Treatment per se was found safe due to the non-significant changes to the body weight, feed intake and water consumption in the animals. The organ weight data suggested that the Biofield Energy Treated test formulation (G4) did not produce any signs of organ related toxicity and it was found to be safe with respect to the most of the vital organs toxicity compared to the normal control (G1).

Table 4. Effect of the test formulation on relative organ weight for the various vital organs in male Sprague Dawley rats.

\begin{tabular}{|c|c|c|c|c|c|c|c|}
\hline Relative organ weight (\%) & G1 & G2 & G3 & G4 & G5 & G6 & G7 \\
\hline Liver & $3.81 \pm 0.12$ & $3.88 \pm 0.11$ & $4.65 \pm 0.07$ & $4.12 \pm 0.27$ & $4.00 \pm 0.09$ & $3.83 \pm 0.10$ & $3.95 \pm 0.11$ \\
\hline Lungs & $0.69 \pm 0.04$ & $0.66 \pm 0.05$ & $0.78 \pm 0.05$ & $0.71 \pm 0.06$ & $0.69 \pm 0.06$ & $0.63 \pm 0.03$ & $0.74 \pm 0.04$ \\
\hline Kidneys & $0.78 \pm 0.03$ & $0.81 \pm 0.03$ & $0.93 \pm 0.04$ & $0.84 \pm 0.04$ & $0.85 \pm 0.03$ & $0.82 \pm 0.01$ & $0.92 \pm 0.05$ \\
\hline Brain & $0.55 \pm 0.02$ & $0.58 \pm 0.02$ & $0.64 \pm 0.03$ & $0.57 \pm 0.02$ & $0.63 \pm 0.04$ & $0.57 \pm 0.02$ & $0.60 \pm 0.02$ \\
\hline Heart & $0.38 \pm 0.02$ & $0.37 \pm 0.01$ & $0.39 \pm 0.02$ & $0.39 \pm 0.02$ & $0.44 \pm 0.05$ & $0.36 \pm 0.01$ & $0.36 \pm 0.02$ \\
\hline Eyes & $0.08 \pm 0.00$ & $0.08 \pm 0.00$ & $0.09 \pm 0.00$ & $0.08 \pm 0.01$ & $0.1 \pm 0.01$ & $0.08 \pm 0.00$ & $0.08 \pm 0.01$ \\
\hline Spleen & $0.24 \pm 0.01$ & $0.20 \pm 0.01$ & $0.23 \pm 0.01$ & $0.25 \pm 0.01$ & $0.27 \pm 0.02$ & $0.23 \pm 0.01$ & $0.22 \pm 0.02$ \\
\hline Jejunum & $1.67 \pm 0.21$ & $1.56 \pm 0.12$ & $1.64 \pm 0.13$ & $1.78 \pm 0.11$ & $1.76 \pm 0.14$ & $1.28 \pm 0.09$ & $1.78 \pm 0.19$ \\
\hline Ileum & $0.26 \pm 0.02$ & $0.31 \pm 0.02$ & $0.31 \pm 0.02$ & $0.32 \pm 0.03$ & $0.33 \pm 0.04$ & $0.28 \pm 0.03$ & $0.34 \pm 0.04$ \\
\hline Caecum & $0.54 \pm 0.02$ & $0.54 \pm 0.04$ & $0.54 \pm 0.03$ & $0.54 \pm 0.02$ & $0.60 \pm 0.03$ & $0.50 \pm 0.04$ & $0.61 \pm 0.02$ \\
\hline Colon & $0.31 \pm 0.02$ & $0.35 \pm 0.02$ & $0.41 \pm 0.04$ & $0.32 \pm 0.02$ & $0.34 \pm 0.03$ & $0.38 \pm 0.03$ & $0.30 \pm 0.03$ \\
\hline Rectum & $0.16 \pm 0.01$ & $0.18 \pm 0.01$ & $0.24 \pm 0.02$ & $0.15 \pm 0.01$ & $0.19 \pm 0.02$ & $0.15 \pm 0.01$ & $0.18 \pm 0.02$ \\
\hline Testis & $0.87 \pm 0.02$ & $0.93 \pm 0.04$ & $1.03 \pm 0.04$ & $1.03 \pm 0.05$ & $1.04 \pm 0.06$ & $1.03 \pm 0.04$ & $1.03 \pm 0.04$ \\
\hline Prostate & $0.24 \pm 0.02$ & $0.27 \pm 0.01$ & $0.23 \pm 0.01$ & $0.22 \pm 0.03$ & $0.25 \pm 0.01$ & $0.23 \pm 0.02$ & $0.23 \pm 0.02$ \\
\hline Pancreas & $0.61 \pm 0.04$ & $0.58 \pm 0.04$ & $0.62 \pm 0.03$ & $0.61 \pm 0.04$ & $0.58 \pm 0.05$ & $0.57 \pm 0.03$ & $0.57 \pm 0.06$ \\
\hline
\end{tabular}

All the values are expressed as the mean \pm SEM. G1: Normal control; G2: Disease control; G3: Levamisole; G4: Biofield Energy Treated test formulation; G5: Untreated test formulation; G6: Biofield Energy Treatment group per se at day -15; G7: Biofield Energy Treated test formulation at day -15.

The relative organ weight is a useful index for the identification of swelling, atrophy or hypertrophy [42]. The increase organ to body ratio indicates the sign of product toxicity, but the experimental results suggested that there was no significant change in most of the vital organs, which ensured that the test formulation was non-toxic to the animals throughout the exposure period at the dose rate of 1105.005 $\mathrm{mg} / \mathrm{kg}$.

\subsection{Assessment of Histopathological Examination}

The effect of the test formulation on histopathological findings in male SD rats is shown in the Figure 2. No significant differences were observed either in gross or in microscopic observation of the tested organs. The histopathological findings also showed no Biofield Energy Healing Treatment related changes were observed in all the 
experimental animals compared with the normal control.

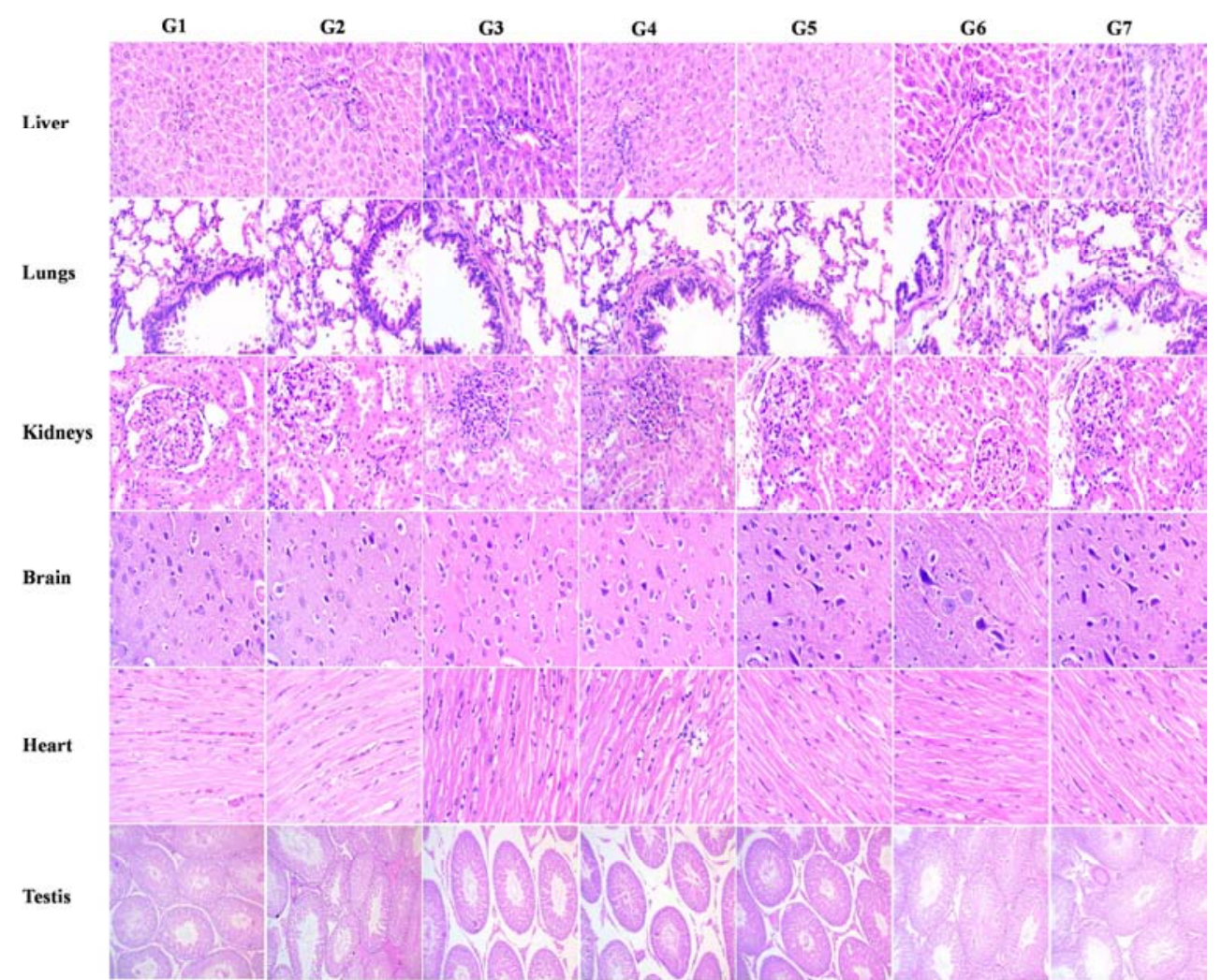

Figure 2. Histopathological photomicrograph of major organs of male Sprague Dawley rats. All the tissues were sectioned transversely and stained with hematoxylin and eosin. G1: Normal control; G2: Disease control; G3: Levamisole; G4: Biofield Energy Treated test formulation; G5: Untreated test formulation; G6: Biofield Energy Treatment group per se at day -15; G7: Biofield Energy Treated test formulation at day -15.

The National Center for Complementary/Alternative Medicine (NCCAM,) reported that about 34\% U.S. populations depends on some forms of complementary health approach, among which energy medicine is one of them. CAM has huge positive aspect compared to the conventional treatment strategy [43]. Overall study findings envisaged that the novel herbomineral based test formulation, exhibited a significant antiinflammatory and immunomodulatory effect in the tested disease model. Therefore, it is assumed that the Biofield Energy Treated herbomineral formulation might be considered as a safe dietary supplement and more powerfull product for boosting the immunity in healthy human and patient.

\section{Conclusions}

Based on the current findings, it can be concluded that the humoral immune response, cell mediated immune response, platelet counts and others supportive biochemical parameters related to immunomodulation were significantly improved in the Biofield Energy Treated test formulation group (G4). The humoral immune response data showed the secondary response of mean hemagglutination (HA) antibody titre was significantly elevated by $112.50 \%$ in the Biofield Energy Treated test formulation (G4) compared to the G2 group. Further, a delayed type hypersensitivity (DTH) response was significantly increased by $111.76 \%, 51.45 \%, 100 \%$, and $64.80 \%$ in the Biofield Energy Treated test formulation, untreated test formulation, Biofield Energy Treatment group per se at day -15 and Biofield Energy Treated test formulation at day -15 , respectively compared to the disease control group (G2). The platelet count was significantly increased by $37.72 \%$ and blood urea nitrogen was significantly decreased by $14.01 \%$ in the Biofield Energy Treated test formulation group (G4) compared to the disease control group (G2). However, no treatment-related changes were observed in any group with respect to the body weight, feed intake, and water intake data in the Biofield Energy Treated test formulation and Biofield Energy Treatment per se group during the course of the experiment. Therefore, The Trivedi Effect ${ }^{\mathbb{B}}$-Biofield Energy Healing Treatment administered remotely by the seven Biofield Energy Healers enhanced the herbomineral test formulation's antiinflammatory and immunomodulatory properties without any toxic effect to the animals throughout the exposure period. Thus, the Biofield Energy Treated test formulation and Biofield Energy Treatment per se in male rats showed an effective anti-inflammatory and immunomodulatory action, and it can be used as a Complementary and Alternative Medicine (CAM) with a safe therapeutic index for various autoimmune disorders such as Lupus, Systemic Lupus Erythematosus, Fibromyalgia, Addison Disease, Hashimoto Thyroiditis, Celiac Disease (gluten-sensitive enteropathy), Multiple Sclerosis, Dermatomyositis, Graves' Disease, Myasthenia Gravis, Pernicious Anemia, Aplastic Anemia, 
Scleroderma, Psoriasis, Rheumatoid Arthritis, Reactive Arthritis, Type 1 Diabetes, Sjogren Syndrome, Crohn's Disease, Vasculitis, Vitiligo, Chronic Fatigue Syndrome and Alopecia Areata, as well as inflammatory disorders such as Irritable Bowel Syndrome (IBS), Asthma, Ulcerative Colitis, Alzheimer's Disease, Parkinson's Disease, Atherosclerosis, Dermatitis, Hepatitis, and Diverticulitis. Further, the Biofield Energy Healing Treated test formulation can also be used in the prevention of immune-mediated tissue damage in cases of organ transplants (for example heart transplants, kidney transplants and liver transplants), for anti-aging, stress prevention and management, and in the improvement of overall health and quality of life.

\section{Acknowledgements}

The authors are grateful to Dabur Research Foundation, Trivedi Science, Trivedi Global, Inc., and Trivedi Master Wellness for the assistance and support during the work.

\section{References}

[1] Hanly WC, Artwohl JE, Bennett BT (1995) Review of polyclonal antibody production procedures in mammals and poultry. ILAR J 37: 93-118.

[2] Heroor S, Beknal A, Mahurkar N (2012) Preliminary investigation for immunomodulation of methanolic extracts of leaves and flowers of Pongamia glabra Vent. in mice model. Adv Lif Sci 2: 170-173.

[3] Farhath S, Vijaya PP, Vima M (2013) Immunomodulatory activity of geranial, geranial acetate, gingerol, and eugenol essential oils: Evidence for humoral and cell-mediated responses. Avicenna J Phytomed 3: 224-230.

[4] Nauta J (2011) Statistics in clinical vaccine trials. Chapter 2 Humoral and cellular immunity. Springer-Verlag Berlin Heidelberg.

[5] Astin JA (1998) Why patients use alternative medicine? Results of a national study. J Am Med Assoc 279: 1548-1553.

[6] MacLennan AH, Wilson DH, Taylor AW (1996) Prevalence and cost of alternative medicine in Australia. Lancet 347: 569-573.

[7] Agarwal R, Diwanay S, Patki P, Patwardhan B (1999) Studies on immunomodulatory activity of Withania somnifera (ashwagandha) extracts in experimental immune inflammation. J Ethnopharmacol 67: 27-35.

[8] Glotter E, Abraham A, Guenzberg IK, Kirson I (1977) Naturally occurring steroidal lactones with $17 \alpha$-oriented side chain structure of withanolide E \& related compounds. J Chem Soc Perkins Trans 1: 341-346.

[9] Sohat B, Gitter E, Abraham A, Lavie D (1967) Antitumor activity of withaferin A. Can Chemother Rep 51: 271-276.

[10] Mazumder PM, Pattnayak S, Parvani H, Sasmal D, Rathinavelusamy P (2012) Evaluation of immunomodulatory activity of Glycyrhiza glabra L roots in combination with zing. Asian Pac J Trop Biomed 2: S15-S20.

[11] Lutgendorf SK, Mullen-Houser E, Russell D, Degeest K,
Jacobson G, Hart L, Bender D, Anderson B, Buekers TE, Goodheart MJ, Antoni MH, Sood AK, Lubaroff DM (2010) Preservation of immune function in cervical cancer patients during chemoradiation using a novel integrative approach. Brain Behav Immun 24: 1231-1240.

[12] Ironson G, Field T, Scafidi F (1996) Massage therapy is associated with enhancement of the immune system's cytotoxic capacity. Int J Neurosci 84: 205-217.

[13] Jain S, Hammerschlag R, Mills P, Cohen L, Krieger R, Vieten C, Lutgendorf S (2015) Clinical studies of biofield therapies: Summary, methodological challenges, and recommendations. Glob Adv Health Med 4: 58-66.

[14] Rubik B (2002) The biofield hypothesis: Its biophysical basis and role in medicine. J Altern Complement Med 8: 703-717.

[15] Trivedi MK, Patil S, Shettigar H, Mondal SC, Jana S (2015) The potential impact of biofield treatment on human brain tumor cells: A time-lapse video microscopy. J Integr Oncol 4: 141.

[16] Trivedi MK, Branton A, Trivedi D, Nayak G, Mondal SC, Jana S (2015) Antimicrobial sensitivity, biochemical characteristics and biotyping of Staphylococcus saprophyticus: An impact of biofield energy treatment. J Women's Health Care 4: 271.

[17] Trivedi MK, Branton A, Trivedi D, Nayak G, Shettigar H, Mondal SC, Jana S (2015) Effect of biofield energy treatment on Streptococcus group B: A postpartum pathogen. J Microb Biochem Technol 7: 269-273.

[18] Trivedi MK, Patil S, Shettigar H, Gangwar M, Jana S (2015) Effect of biofield treatment on antimicrobials susceptibility pattern of Acinetobacter baumannii - An Experimental Study. J Clin Diagn Res 3: 1.

[19] Trivedi MK, Branton A, Trivedi D, Nayak G, Bairwa K, Jana S (2015) Effect of biofield treatment on physical, thermal, and spectral properties of SFRE 199-1 mammalian cell culture medium. Advances in Biochemistry 3: 77-85.

[20] Trivedi MK, Branton A, Trivedi D, Nayak G, Mondal SC, Jana S (2015) Evaluation of antibiogram, genotype and phylogenetic analysis of biofield treated Nocardia otitidis. Biol Syst Open Access 4: 143.

[21] Trivedi MK, Branton A, Trivedi D, Nayak G, Gangwar M, Jana S (2015) Antibiogram, biochemical reactions, and genotypic pattern of biofield treated Pseudomonas aeruginosa. J Trop Dis 4: 181.

[22] Trivedi MK, Branton A, Trivedi D, Shettigar H, Bairwa K, Jana S (2015) Fourier transform infrared and ultravioletvisible spectroscopic characterization of biofield treated salicylic acid and sparfloxacin. Nat Prod Chem Res 3: 186.

[23] Trivedi MK, Patil S, Shettigar H, Bairwa K, Jana S (2015) Effect of biofield treatment on spectral properties of paracetamol and piroxicam. Chem Sci J 6: 98.

[24] Trivedi MK, Tallapragada RM, Branton A, Trivedi D, Nayak G, Latiyal O, Jana S (2015) Potential impact of biofield treatment on atomic and physical characteristics of magnesium. Vitam Miner 3: 129.

[25] Trivedi MK, Branton A, Trivedi D, Nayak G, Panda P, Jana S (2016) Gas chromatography-mass spectrometric analysis of isotopic abundance of ${ }^{13} \mathrm{C},{ }^{2} \mathrm{H}$, and ${ }^{18} \mathrm{O}$ in biofield energy treated $p$-tertiary butylphenol (PTBP). American Journal of Chemical Engineering 4: 78-86. 
[26] Trivedi MK, Branton A, Trivedi D, Nayak G, Sethi KK, Jana S (2016) Gas chromatography-mass spectrometry based isotopic abundance ratio analysis of biofield energy treated methyl-2-napthylether (Nerolin). American Journal of Physical Chemistry 5: 80-86.

[27] Trivedi MK, Branton A, Trivedi D, Nayak G, Mondal SC, Jana S (2015) Evaluation of biochemical marker - glutathione and DNA fingerprinting of biofield energy treated Oryza sativa. American Journal of BioScience 3: 243-248.

[28] Trivedi MK, Branton A, Trivedi D, Nayak G, Gangwar M, Jana S (2016) Molecular analysis of biofield treated eggplant and watermelon crops. Adv Crop Sci Tech 4: 208.

[29] Trivedi MK, Branton A, Trivedi D, Nayak G, Mondal SC, Jana S (2015) Morphological characterization, quality, yield and DNA fingerprinting of biofield energy treated alphonso mango (Mangifera indica L.). Journal of Food and Nutrition Sciences 3: 245-250.

[30] Trivedi MK, Tallapragada RM, Branton A, Trivedi D, Nayak G, Latiyal O, Jana S (2015) Characterization of physical and structural properties of aluminum carbide powder: Impact of biofield treatment. J Aeronaut Aerospace Eng 4: 142.

[31] Trivedi MK, Tallapragada RM, Branton A, Trivedi D, Nayak G, Latiyal O, Jana S (2015) The potential impact of biofield energy treatment on the atomic and physical properties of antimony tin oxide nanopowder. American Journal of Optics and Photonics 3: 123-128.

[32] Trivedi MK, Patil S, Tallapragada RM (2013) Effect of bio field treatment on the physical and thermal characteristics of vanadium pentoxide powders. J Material Sci Eng S 11: 001.

[33] Ladics GS (2007) Primary immune response to sheep red blood cells (SRBC) as the conventional T-cell dependent antibody response (TDAR) test. J Immunotoxicol 4: 149-152.

[34] Joharapurkar AA, Zambad SP, Wanjari MM, Umathe SN (2003) In vivo evaluation of antioxidant activity of alcoholic extract of Rubia cordifolia Linn. and its influence on ethanolinduced immunosuppression. Indian J Pharmacol 35: 232-236.
[35] Feldman BF, Zinkl JG, Jain VC. Laboratory techniques for avian hematology," in Schalm's Veterinary Hematology, $\left(5^{\text {th }}\right.$ Edn) Lippincott Williams \& Wilkins, Toronto, Canada, 2000.

[36] OECD, OECD Guideline for Testing of Chemicals, vol. 420, Organization for Economic Cooperation and Development, Paris, France, 1992.

[37] Chanda S, Dave R, Kaneria M, Shukla V (2012) Acute oral toxicity of Polyalthia longifolia var. pendula leaf extract in wistar albino rats. Pharmaceutical Biol 50: 1408-1415.

[38] Kawai R, Ito S, Aida T, Hattori H, Kimura T, Furukawa T, Mori K, Sanbuissho A, Kawada T (2013) Evaluation of primary and secondary responses to a T-cell-dependent antigen, keyhole limpet hemocyanin, in rats. J Immunotoxicol 10: $40-48$

[39] Naik SR, Gavankar C, Thakare VN (2015) Immunomodulatory activity of Withania somnifera and Curcuma longa in animal models: Modulation of cytokines functioning. Pharmacologia 6: 168-177.

[40] Nagalakshmi D, Sridhar K, Parashuramulu S (2015) Replacement of inorganic zinc with lower levels of organic zinc (zinc nicotinate) on performance, hematological and serum biochemical constituents, antioxidants status and immune responses in rats, Vet World 8: 1156-1162.

[41] Ziauddin M, Phansalkar N, Patki P, Diwanay S, Patwardhan B (1996) Studies on immunomodulatory effects of a ashwagandha. J Ethnopharmacol 50: 69-76.

[42] Amresh GR, Singh PN, Rao CV (2008) Toxicological screening of traditional medicine Laghupatha (Cissampelos pareira) in experimental animals. J Ethnopharmacol 116: 454460.

[43] Clarke TC, Black LI, Stussman BJ, Barnes PM, Nahin RL (2015) Trends in the use of complementary health approaches among adults: Unites States, 2002-2012. National health statistics reports. no 79. Hyattsville, MD: National Center for Health Statistics. 